\title{
Removal of Cd (II) from Aqueous Media by Adsorption onto Chemically and Thermally Treated Rice Husk
}

\author{
María Camila Hoyos-Sánchez, ${ }^{1}$ Angie Carolina Córdoba-Pacheco, ${ }^{1}$ \\ Luis Fernando Rodríguez-Herrera, ${ }^{2}$ and Ramiro Uribe-Kaffure ${ }^{3}$ \\ ${ }^{1}$ Department of Biology, University of Tolima, Altos de Santa Helena, C. P. 730006 Ibagué, Colombia \\ ${ }^{2}$ Department of Chemistry, University of Tolima, Altos de Santa Helena, C. P. 730006 Ibagué, Colombia \\ ${ }^{3}$ Department of Physics, University of Tolima, Altos de Santa Helena, C. P. 730006 Ibagué, Colombia \\ Correspondence should be addressed to Ramiro Uribe-Kaffure; rauribe@ut.edu.co
}

Received 8 March 2017; Revised 9 May 2017; Accepted 15 May 2017; Published 6 June 2017

Academic Editor: Wenshan Guo

Copyright (C) 2017 María Camila Hoyos-Sánchez et al. This is an open access article distributed under the Creative Commons Attribution License, which permits unrestricted use, distribution, and reproduction in any medium, provided the original work is properly cited.

\begin{abstract}
Chemically and thermally treated rice husks were evaluated as a potential decontaminant of toxic Cd (II) in aqueous media. Rice husk $(\mathrm{RH})$, a by-product from rice milling, was chemically treated with $\mathrm{HCl}$ and $\mathrm{NaOH}$. Then, thermal treatments to 300,500 , and $700^{\circ} \mathrm{C}$ were applied. The chemical composition and morphological characteristics of RH were evaluated by different techniques. The specific surface area analysis of RH samples by BET nitrogen adsorption method provided specific surface areas ranging from 6 to $14 \mathrm{~m}^{2} / \mathrm{g}$. SEM, FTIR, and EDX analyses of RH were carried out to determine the surface morphology, functional groups involved in metal binding mechanism, and $\mathrm{C} / \mathrm{O}$ and $\mathrm{C} / \mathrm{Si}$ ratios, respectively. The maximum Cd (II) adsorption capacity was $28.27 \mathrm{mg} / \mathrm{g}$ at an optimum $\mathrm{pH}, 6.0$. The kinetic studies revealed that adsorption process followed the pseudo-second-order kinetic model.
\end{abstract}

\section{Introduction}

Although many different definitions have been proposed to the term "heavy metal," some based on density, some on atomic number or atomic weight, and some on chemical properties [1], the term is often used to denote a group of metals and semimetals (metalloids) that have been associated with contamination and potential toxicity or ecotoxicity.

While some are essential for growth, reproduction, and survival of living organisms, the contamination by heavy metals has become a significant environmental problem $[2,3]$. In order to minimize the hazardous effects of such elements on the environment and human health, there is a particular need for the development of efficient techniques for removing heavy metals from water sources.

Among the heavy metals, cadmium, which exists commonly in Cd (II) form in aqueous media, poses severe risks to human health. It has been reported that cadmium intoxication can lead to kidney [4], bone [5], and pulmonary [6] damage among others. Therefore, the increase in environmental cadmium concentrations, mainly for its use in industrial processes, added to the fact that it has not shown any physiological function within the human body [7], validates the study of techniques for cadmium removal from aqueous media.

In recent years, a wide variety of techniques have been applied for removal of heavy metal from aqueous media: ion exchange [8], bioremediation by microorganism [9], biometallurgy [10], and bioelectrochemical metal recovery [11], among others. In this context, adsorption has been referenced as an efficient and easy-to-use alternative. By this method, environmental pollutants are removed and concentrated on a specific area for better handling and disposal. Materials such as activated carbon and clays, among others, have shown a potential contaminants adsorbent capacity. However, in the need to find inexpensive and high availability materials, there are a growing number of studies on agroindustrial waste as bagasse from sugar [12], stem of papaya [13], shell bean [14], banana peel [15], coffee residues [16], orange peel [17], among others, to be used as adsorbent materials. 
Previous reports have shown the potential of raw rice husk and rice husk ash as adsorbent materials for metals in aqueous media [18-20]; however, chemical and physical changes on the material are required to optimize their adsorbent capacity [21]. This study was aimed to evaluate the Cd (II) adsorption capacity onto different adsorbent materials obtained from rice husk chemically and thermally treated (not necessarily as ash). In addition, it tries to determine the experimental $\mathrm{pH}$ and equilibrium time conditions required to achieve the highest percentage of Cd (II) adsorption onto rice husk.

\section{Materials and Methods}

2.1. Samples Preparation. Rice (Oryzika-I) husks were provided by a local industry (Molino Caribe), located in Espinal city, Colombia. To prepare the samples, the rice husks were manually cleaned and thoroughly washed with distilled water to remove all dirt. Then rice husks were crushed and passed through a steel sieve; particle sizes $\leq 100 \mu \mathrm{m}$ were obtained. At this point, chemical composition analysis was performed. Without any other physical or chemical treatment on rice husk, we select the first sample, RHw (rice husk without treatment).

Chemical and Thermal Treatment on Rice Husks. According to previous reports, the treatment of rice husks with $\mathrm{HCl}$ helps in removing impurities such as inorganic salts [22]. Besides, it also helps to remove traces of different oxides such as potassium oxide $\left(\mathrm{K}_{2} \mathrm{O}\right)$ from the use of fertilizers in rice cultivation [23]. On the other hand, washing with $\mathrm{NaOH}$ generates an increase in the adsorption capacity of rice husk, because it can partially degrade some components of the husk, exposing reactive functional groups, as $\mathrm{OH}$, which could retain the contaminating molecules $[24,25]$. Also, this washing removes surface impurities that can interfere with the adsorption [21].

According to the above, cleaned and sieved rice husk was soaked in $0.5 \mathrm{M} \mathrm{HCl}$ solution $(1: 20)$ at room temperature for $4 \mathrm{~h}$ in permanent agitation on a shaker to $200 \mathrm{RPM}$. Rice husk was then washed, filtered, and soaked in $0.5 \mathrm{M} \mathrm{NaOH}$ solution $(1: 20)$ at the same above-mentioned conditions. Finally, rice husk was repeatedly washed with distillated water and dried at $40^{\circ} \mathrm{C}$ for $48 \mathrm{~h}$. This treated rice husk was designated as RHc (rice husk chemically treated).

In order to choose the adequate temperatures for the rice husk's thermal treatment, at this time a thermogravimetric analysis was carried out in oxygen flow, with temperature rise of $10^{\circ} \mathrm{C}$ per minute until $700^{\circ} \mathrm{C}$, in a STA 7200 TGA analyzer. From thermogravimetric results, the working temperatures were chosen, coinciding with temperatures for which the greatest mass losses occur. Samples were then heated by increasing the temperature for 3 hours to the desired value and maintained at that value for 3 hours.

2.2. Samples Characterization. Specific surface area determination was conducted to assess the structural changes of the rice husk induced by chemical and thermal treatment. Specific surface area was measured according to the
Brunauer-Emmett-Teller (BET) method, based on the nitrogen adsorption by sample surface. The assays were conducted at $77 \mathrm{~K}$ in a surface area analyzer (Autosorb-iQ 07165, Quantachrome Instrument).

The morphological characteristics and elemental analysis of rice husks were evaluated using a JEOL, 6490-LV scanning electron microscope equipped with an EDX (Inca Energy 250 EDS System LK-IE250, Oxford). The rice husk samples were covered with a thin layer of gold and an electron acceleration voltage of $20 \mathrm{kV}$ was applied.

The functional groups on rice husks were characterized by a Fourier Transform Infrared Spectrometer (Thermo Nicolet NEXUS 670 FTIR). The spectral range was varied from 4000 to $400 \mathrm{~cm}^{-1}$.

2.3. Adsorption Experiments. Working solutions of Cd (20, $40,60,80$, and $100 \mathrm{mg} / \mathrm{L}$ ) were prepared by diluting the stock solution $(1000 \mathrm{mg} / \mathrm{L})$ in deionized water. Each adsorbent material (at a concentration of $3 \mathrm{~g}$ of sorbent/L of solution) was soaked in a Cd (II) solution. Solutions were under constant stirring at room temperature $\left(22^{\circ} \mathrm{C}\right)$ for 5 days; $\mathrm{pH}$ was maintained at 6 during the whole process. Finally, the solutions were filtered and quantification of residual $\mathrm{Cd}$ (II) in solutions was carried out using atomic absorption spectrometry (Perkin Elmer 3110).

The adsorption of Cd (II) ions onto rice husk materials was calculated using the following equation:

$$
q_{e}=\frac{\left(C_{o}-C_{e}\right) V}{m}
$$

where $q_{e}$ is the amount of metal ions adsorbed onto rice husk $(\mathrm{mg} / \mathrm{g}), C_{o}$ and $C_{e}(\mathrm{mg} / \mathrm{L})$ are the initial and equilibrium concentrations of metal ions, $V(\mathrm{~L})$ is the volume of solution, and $m(\mathrm{~g})$ is the adsorbent mass. Similarly, the percentage of adsorption for each adsorbent material was determined by the following equation:

$$
\% \text { Ads }=\frac{C_{o}-C_{e}}{C_{o}} \times 100 .
$$

2.4. pH and Kinetics of Adsorption Studies for the Best Sample. Once the material with the best adsorption capacity was found, the effect of $\mathrm{pH}$ on $\mathrm{Cd}$ (II) adsorption onto this material was evaluated. The best adsorbent material was soaked in different $\mathrm{Cd}$ solutions $(20 \mathrm{mg} / \mathrm{L})$ at $\mathrm{pH} 4,5$, and 6 . It was under constant stirring at room temperature $\left(22^{\circ} \mathrm{C}\right)$ for 6 days. From capacity adsorption results, the best working $\mathrm{pH}$ value was determined.

In order to evaluate the reaction time required in the adsorption process, the best adsorbent material, at the best $\mathrm{pH}$ value, was placed in contact with eleven independent Cd (II) solutions $(100 \mathrm{mg} / \mathrm{L})$. It was under constant stirring at room temperature $\left(22^{\circ} \mathrm{C}\right)$. Pseudo-first-order and pseudosecond-order kinetic models were applied to results of adsorption capacity in order to predict the nature of the kinetics.

All the experiments were performed in triplicate; ANOVA and Fisher's exact tests were employed for statistical analyses of data. 


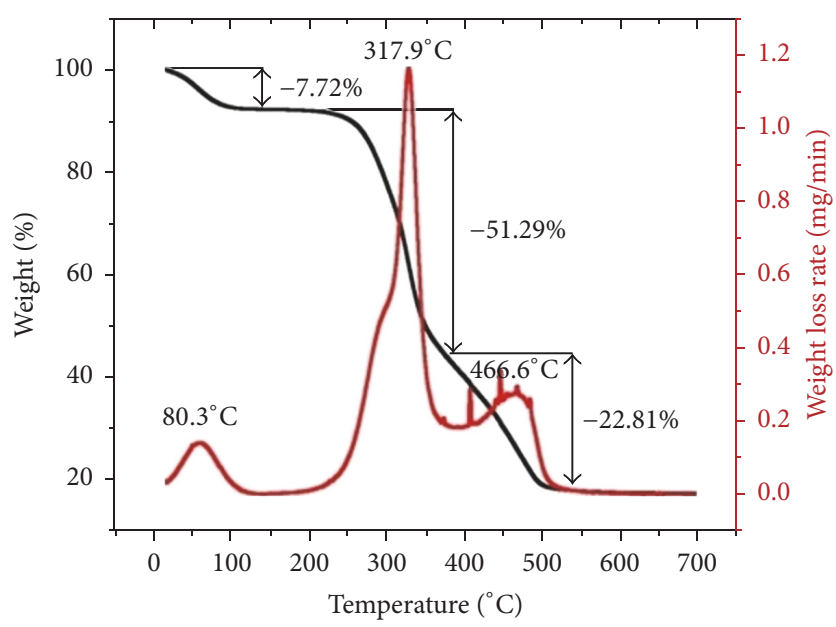

FIGURE 1: Raw rice husk's thermogravimetric analyses.

TABLE 1: Raw rice husk chemical composition.

\begin{tabular}{lc}
\hline Compound & Percentage (\%) \\
\hline Cellulose & 30.6 \\
Hemicellulose & 18.3 \\
Lignin & 29.9 \\
Ash & 19.5 \\
Moisture & 4.9 \\
\hline
\end{tabular}

\section{Results and Discussion}

3.1. Sample Preparation. Table 1 shows the RHw composition determined by chemical analysis. These results are in the same range of previously reported values [26] and are significant since superficial $\mathrm{OH}$ groups present in compounds such as cellulose, hemicellulose, and lignin could interact with the contaminants in the adsorption process [27]. In addition, chemical analysis shows that rice husk contains $19 \%$ ash, which, according to previous reports, is composed of $95 \%$ silica $\left(\mathrm{SiO}_{2}\right)$, an important aspect for its use as adsorbent material [28].

Thermogravimetric analyses (Figure 1) showed that the overall mass loss of rice husk can be divided into steps related to loss of moisture, hemicellulose, cellulose, and lignin. Thus, a mass loss of $7.72 \%$ at $100^{\circ} \mathrm{C}$ was confirmed due to the elimination of moisture retained in this material. Afterwards, a second step was obtained between 250 and $350^{\circ} \mathrm{C}$, corresponding to the highest mass loss (51.29\%). This step is related to hemicellulose and cellulose decomposition, as well as loss of the remaining adsorbed water [29]. Lignin decomposition occurs in the 360 to $520^{\circ} \mathrm{C}$ range. Finally, no significant mass loss was observed at higher temperatures indicating the presence of oxides.

From TGA results, the calcination temperatures for thermal treatment on rice husk were chosen: $300^{\circ} \mathrm{C}$ near to the maximum mass loss peak and $500^{\circ} \mathrm{C}$ after the loss of compounds that could influence the material adsorption capacity. Additionally, the $700^{\circ} \mathrm{C}$ value was selected, because no more mass losses are presented and only rice husk mineral
TABLE 2: Features of all prepared samples.

\begin{tabular}{lc}
\hline Material & Rice husk features \\
\hline RHw & Without any treatment \\
RHc & With chemical treatment \\
RHc300 & With chemical and thermal treatment to $300^{\circ} \mathrm{C}$ \\
RHc500 & With chemical and thermal treatment to $500^{\circ} \mathrm{C}$ \\
RHc700 & With chemical and thermal treatment to $700^{\circ} \mathrm{C}$ \\
\hline
\end{tabular}

residue remains. After this thermal treatment, calcined samples at 300,500 , and $700^{\circ} \mathrm{C}$ were obtained (namely, RHc300, RHc500, and RHc700, resp.).

In summary, after chemical and thermal treatments on rice husks, five materials were prepared and physiochemically characterized. Onto these materials, Cd (II) adsorption capacity was evaluated. Table 2 shows the five materials prepared for Cd (II) adsorption.

3.2. Samples Characterization. The specific surface area of rice husk samples was determined by nitrogen adsorption isotherm at $77 \mathrm{~K}$ using an Autosorb-iQ 07165, Quantachrome Instrument. Values of specific surface area of rice husk samples were calculated by Brunauer-Emmett-Teller (BET) method and are consigned in the last column of Table 4. There, an important decrease in the specific surface area value of rice husk chemically treated $\left(4 \mathrm{~m}^{2} / \mathrm{g}\right)$ in relation to the sample without treatment $\left(13 \mathrm{~m}^{2} / \mathrm{g}\right)$ can be seen. This change can be attributed to the effects of $\mathrm{NaOH}$ on the material either by partial degradation of some components of the rice husk, generating merging of smaller pores (micropores) into large pores (mesopores) [30], or because of the fixing of $\mathrm{NaOH}$ on the surface of the material which may cause blockage in the pores.

With the thermal treatment, RHc300 sample showed the greatest specific surface area of all studied materials, $14 \mathrm{~m}^{2} / \mathrm{g}$, probably due to changes in pore volume. However, the higher calcination temperature, the smaller specific surface area, as can be seen for samples RHc500 $\left(7 \mathrm{~m}^{2} / \mathrm{g}\right)$ and RHc700 $\left(6 \mathrm{~m}^{2} / \mathrm{g}\right)$. In this regard, Della et al. [31] reported that higher increases in rice husk calcining temperature cause an agglomeration effect, diminishing porosity. But also our own previous research results (without publishing) indicate that, in rice husk treated with $\mathrm{NaOH}$ and calcined at $700^{\circ} \mathrm{C}$, silicon dioxides were organized into a crystalline structure known as cristobalite. Due to the fact that the rice husk specific surface area increases when silica in the ash is amorphous [31, 32], the presence of cristobalite could explain the decrease in specific surface area in RHc700 sample.

Figure 2 shows SEM microphotographs of RHw, RHc, and RHc300 samples. Image of RHw sample (Figure 2(a)) shows a section of the rice husk where well-defined and organized cavities are observed. Although in image of RHc sample (Figure 2(b)) the structure is preserved, some cracking of cavities can be observed. This cracking, which generates deformation of the pores and loss of regularity, could be explained by the intracellular breakdown that $\mathrm{NaOH}$ causes [33]. Furthermore, some agglomerations observed on 


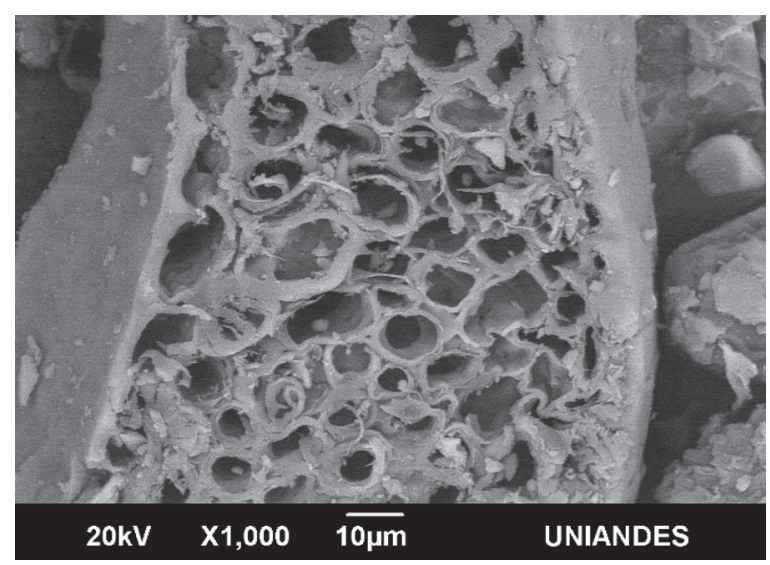

(a)

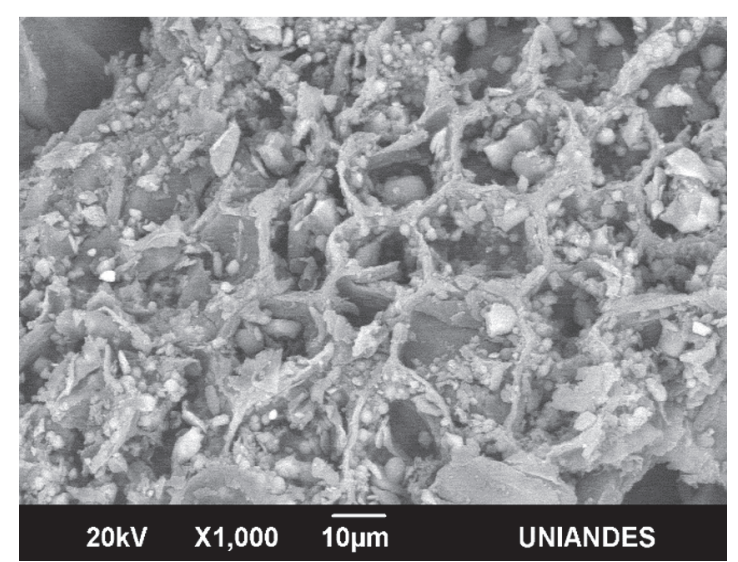

(b)

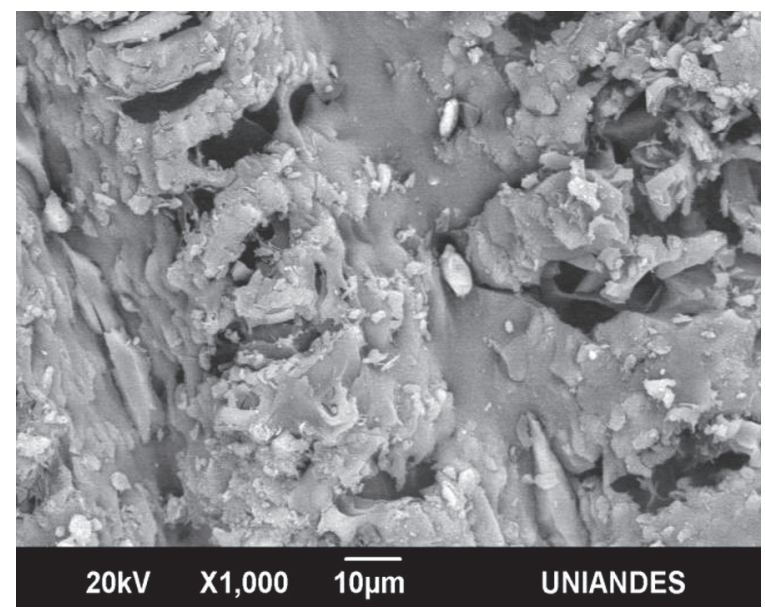

(c)

Figure 2: Microphotographs of RHw (a), RHc (b), and RHc300 (c) materials.

the material may possibly be due to $\mathrm{NaOH}$ fixed on the surface.

RHc300 sample microphotograph (Figure 2(c)) shows that the collapse of rice husk structure continues not only by intracellular breakdown caused by $\mathrm{NaOH}$ but also by the combustion that generates degradation in the material structure and loss of part of carbon phase.

Figure 3 shows SEM microphotographs of RHc500 and RHc700 samples. Both samples show a surface with less roughness than RHc300 (Figure 2(c)) sample, but RHc700 (Figure 3(b)) has the cleanest surface with well-defined pores on it.

Figures 4 and 5 show the IR spectrum for thermally untreated and treated samples, respectively. In all spectra, above $1,200 \mathrm{~cm}^{-1}$ the organic part of rice husk can be distinguished, and below $1,200 \mathrm{~cm}^{-1}$ the presence of vibrations corresponding to different forms of silicon appears [34].

Figure 4 shows the IR spectrum for RHw and RHc samples. RHw sample spectrum (dashed line) has some highlighted bands, as the characteristic of hydroxyl groups $(-\mathrm{OH})$ at $3,418 \mathrm{~cm}^{-1}$, the vibration of $\mathrm{C}-\mathrm{H}$ at $2,918 \mathrm{~cm}^{-1}$, and the one at $1,650 \mathrm{~cm}^{-1}$ corresponding to $\mathrm{C}=\mathrm{C}$ bond vibration. These bands, also reported by other authors [35, 36], correspond to the main organic compounds of the rice husk: cellulose, hemicellulose, and lignin. Also, a significant band at $1,100 \mathrm{~cm}^{-1}$, evidence of $\mathrm{Si}-\mathrm{O}$ bonds present in cyclic siloxanes, is observed. The presence of cyclic siloxanes could be confirmed by peaks occurring between 470 and $800 \mathrm{~cm}^{-1}$. Additionally, the peaks at 1,101 and $3,418 \mathrm{~cm}^{-1}$, distinctive of $-\mathrm{Si}-\mathrm{O}$ and $-\mathrm{O}-\mathrm{H}$, could be evidence of silanol groups $[34,36]$.

There are few differences in spectra shown in Figure 4; however, for RHc sample (solid line), widening of the band corresponding to the vibrations of the $\mathrm{OH}$ and a decrease in the intensity of the band associated with cyclic siloxanes at $1,100 \mathrm{~cm}^{-1}$ can be seen. These changes are only due to the chemical treatment.

On the other hand, there are significant differences between thermally treated and untreated rice husks. Figure 5 shows the spectrum of all thermally treated samples, RHc300, RHc500, and RHc700.

It can be seen that as the heat treatment temperature increases, the characteristic bands of main rice husk organic 


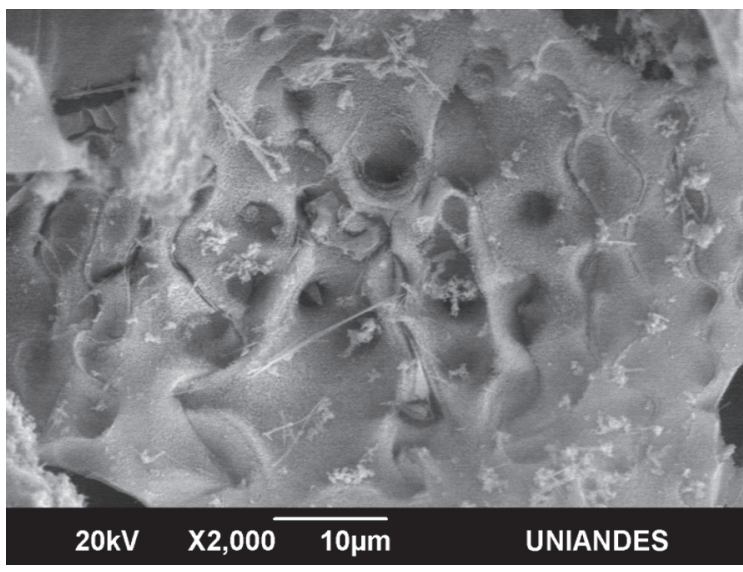

(a)

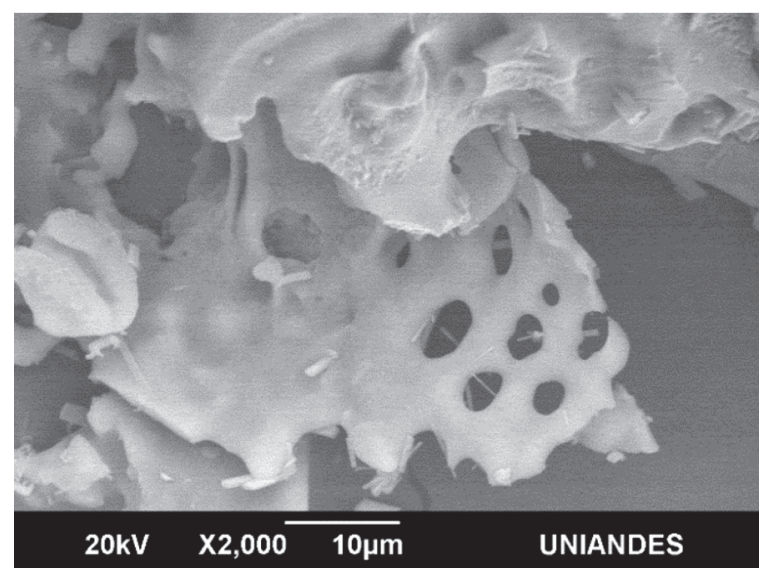

(b)

Figure 3: Microphotographs of RHc500 (a) and RHc700 (b) materials.

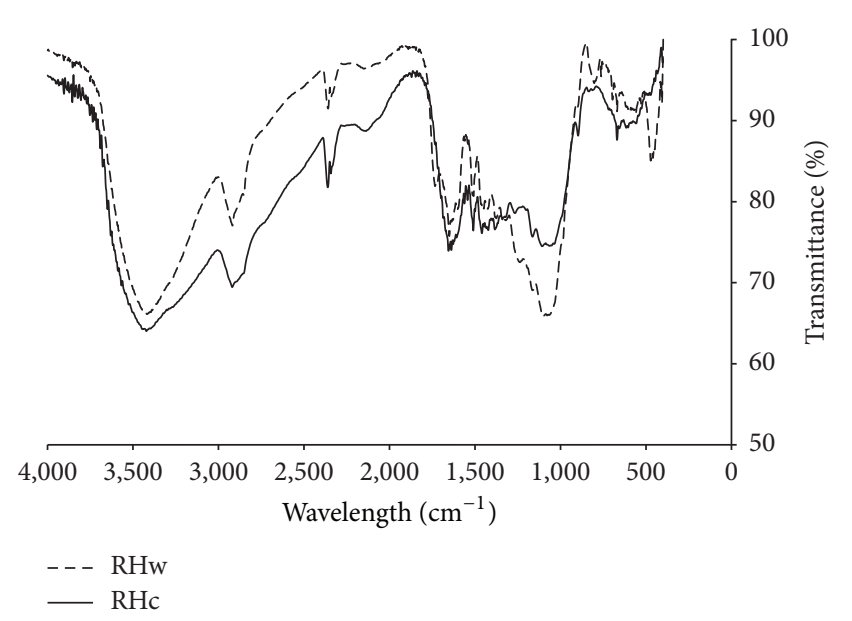

FIGURE 4: IR spectrum of RHw (dashed line) and RHc (solid line) samples.

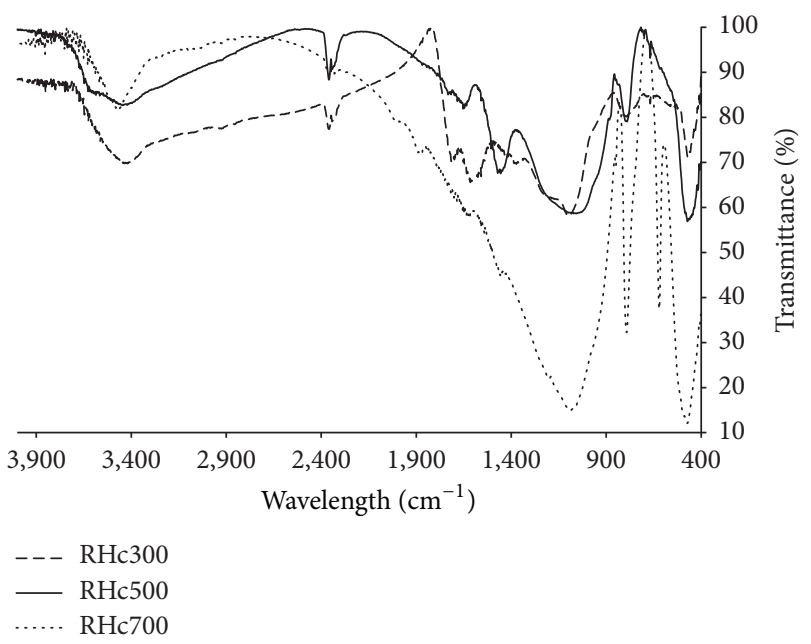

FIGURE 5: IR spectrum of RHc300 (dashed line), RHc500 (solid line), and RHc700 (dotted line) samples.
TABLE 3: C/O and C/Si ratios obtained by EDX analysis for all adsorbent materials.

\begin{tabular}{lcc}
\hline Material & C/O & Ratio \\
\hline$R H w$ & 1.8 & $\mathrm{C} / \mathrm{Si}$ \\
$\mathrm{RHc}$ & 1.5 & 4.5 \\
$R H c 300$ & 1.1 & 18.9 \\
$\mathrm{RHc500}$ & 0.5 & 1.2 \\
$R H c 700$ & 0.3 & 0.6 \\
\hline
\end{tabular}

compounds are decreasing. On the contrary, the band corresponding to the $-\mathrm{Si}-\mathrm{O}$ vibration $\left(1,100 \mathrm{~cm}^{-1}\right)$ is gaining intensity, probably due to the formation of silica-rich ashes.

The $\mathrm{C} / \mathrm{O}$ and $\mathrm{C} / \mathrm{Si}$ relationships for each sample were obtained by energy-dispersive X-ray spectroscopy (EDX) analysis and are contained in Table 3 . According to the results, the RHw material has the highest $\mathrm{C} / \mathrm{O}$ ratio, because the rice husk is composed mostly of carbonaceous rings of lignin, cellulose, and hemicellulose. The $\mathrm{C} / \mathrm{O}$ relationship for chemically treated husk rice (RHc) is lower than that in the raw material $(\mathrm{RHw})$; this agrees with IR results that showed an increase in $\mathrm{OH}$ groups for RHc sample. Besides, the $\mathrm{C} / \mathrm{Si}$ ratio for the $\mathrm{RHc}$ material increases relative to the one for raw material (see Table 3), indicating a decrease in silicon (as reported in the IR analysis). The Si decrease may be due to effect of $\mathrm{NaOH}$ washing on the material, since it has been reported that $\mathrm{NaOH}$ is capable of reacting with the silicon present in the husk forming sodium silicates, which are soluble and could be removed with water washes carried out after chemical treatment of the husk [25, 37].

Table 3 also shows that for heat treated materials a progressive decrease in $\mathrm{C} / \mathrm{O}$ and $\mathrm{C} / \mathrm{Si}$ ratios is observed. This is due to the combustion process that generates progressive loss in carbon phase, while the silicon remains constant (relative to the RHc sample). 
TABLE 4: Specific surface area, adsorption capacity, and percentage of Cd (II) adsorption onto adsorbent materials.

\begin{tabular}{lccc}
\hline Material & $\begin{array}{c}\text { Adsorption } \\
\text { Capacity }(\mathrm{mg} / \mathrm{g})\end{array}$ & $\begin{array}{c}\text { Adsorption } \\
\text { Percentage }(\%)\end{array}$ & $\begin{array}{c}\text { Specific surface area } \\
\text { BET }\left(\mathrm{m}^{2} / \mathrm{g}\right)\end{array}$ \\
\hline RHw & 7.44 & 31 & 13 \\
RHc & 17.45 & 75 & 4 \\
RHc300 & 28.27 & 95 & 14 \\
RHc500 & 2.03 & 5 & 7 \\
RHc700 & 2.03 & 8 & 6 \\
\hline
\end{tabular}

3.3. Adsorption Experiments. Experimental data of Cd (II) adsorption on all studied materials were fitted to the Langmuir and Freundlich isotherms models. According to the parameters obtained in the setting of these models, the RHw and RHc materials adapt to Freundlich isotherm model, while the remaining materials, $\mathrm{RHc} 300, \mathrm{RHc500}$, and $\mathrm{RHc} 700$, fit to Langmuir isotherm model.

Results of Cd (II) adsorption analysis for all samples are shown in Table 4. Although the major factors influencing adsorption are the textural characteristics of adsorbents, the results obtained and given in Table 4 do not show a direct relationship between the adsorption capacity and specific surface area of the samples. This could indicate that adsorbate-adsorbent interaction occurs mainly thanks to the active sites and functional groups present in each material. These results agree with previously reported studies [38, 39].

From data in Table 4, it can be seen that adsorption capacity for RHc sample was increased by more than 2 times the value of RHw sample. This indicates that chemical treatment with $\mathrm{NaOH}$ effectively generates changes in the original structure of rice husk, probably causing surface groups that act as active sites and promote the affinity between $\mathrm{Cd}$ (II) and the sample. In this regard, it has been reported that modification of lignocellulosic residues by $\mathrm{NaOH}$ treatment produces changes in the fibers structure of biomass, which improve its accessibility properties, in addition to possibly adding active groups on the surface of material or leaving exposed surface groups because degradation caused on structure [24].

The RHc300 sample showed the highest Cd (II) adsorption capacity. This is probably due to chemical characteristics: its structure still has a carbon-oxygen phase from the organic composition of raw rice husk; it has phase silicon groups such as $\mathrm{SiOH}$ available on the surface, resulting from the thermal treatment; and it possibly has active $\mathrm{OH}$ - groups incorporated by treating with $\mathrm{NaOH}$. The presence of all these active groups on the surface of CAq300 favors interaction between sample and Cd (II), generating greater efficiency in this material compared to others [40-43].

The similarities in the physicochemical characteristics of RHc500 and RHc700 samples could explain the coincidence in their Cd (II) adsorption capacities.

Finally, from adsorption analysis, RHc300 was determined as the best sample in adsorbing Cd (II); therefore this material was selected to determine the effect of $\mathrm{pH}$ and kinetics of equilibrium on Cd (II) adsorption.

3.4. pH and Kinetics of Adsorption Studies for RHc300 Sample. The effect of solution $\mathrm{pH}$ on Cd (II) adsorption for RHc300 sample (selected as the best adsorbent) was studied. The

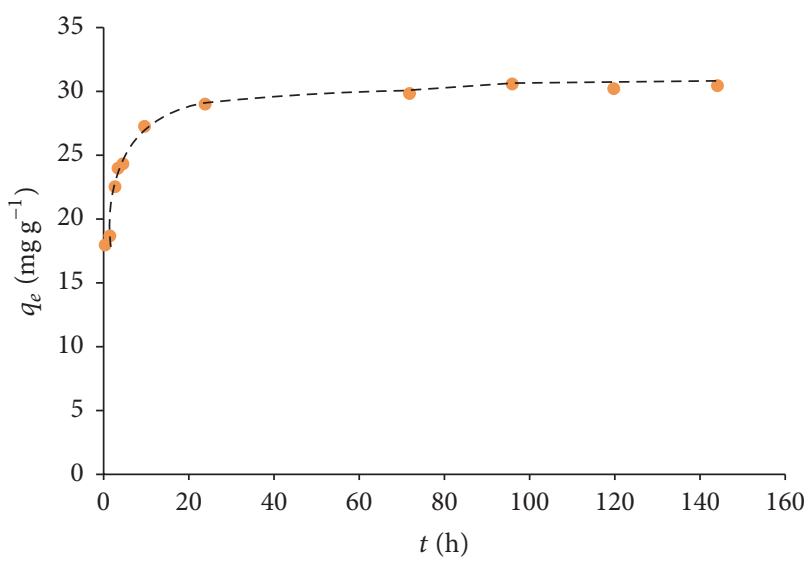

FIgure 6: Equilibrium time for Cd (II) adsorption onto RHc300 sample at $\mathrm{pH}=6$. Dashed line only shows data trend.

results showed that at $\mathrm{pH} 5$ and 6 the adsorption percentages are similar (98.83 and $98.89 \%$, resp.), whereas the adsorption at $\mathrm{pH} 4$ was smaller, $98.36 \%$. Statistically, it was determined that the means of adsorption are different.

Figure 6 shows the Cd (II) adsorption capacity $\left(q_{e}\right)$ on RHc300 sample as a function of time. From the graph, it was determined that equilibrium time for adsorption is 72 hours. After this time, changes in the adsorption capacity are less than $1 \mathrm{mg} / \mathrm{g}$.

From experimental data of equilibrium time for Cd (II) adsorption onto RHc300 sample, the highest correlation coefficient $\left(R^{2}=0.999\right)$ was obtained for the pseudo-secondorder kinetic model. This implies that chemisorption is the rate-limiting step in the adsorption process [44]. As chemisorption is characterized by formation of monolayer, this result is consistent with our assumption of Langmuir isotherm model, which states that the monolayer adsorption occurs on specific sites of the homogeneous surface. Additionally, these results are also consistent with those obtained by Kumar et al. [45] who found that adsorption of Cd (II) on rice husk ash fits the pseudo-second-order kinetic model.

\section{Conclusions}

The chemical $(\mathrm{HCl}$ and $\mathrm{NaOH})$ and thermal treatments $\left(300^{\circ} \mathrm{C}\right.$ for $\left.3 \mathrm{~h}\right)$ on rice husk increase its $\mathrm{Cd}$ (II) removal efficiency almost four times. Although chemical and thermal treatments produced changes in the specific surface area of 
studied samples, the adsorption capacity of samples shows no direct relationship with their specific surface area. Thus, it could be considered that, in this system, the binding adsorbate-adsorbent is mainly due to the presence of active groups on the surface of adsorbent materials.

The maximum Cd (II) adsorption capacity was $28.27 \mathrm{mg} / \mathrm{g}$ at an optimum $\mathrm{pH} 6.0$ for RHc300 sample. On the other hand, the kinetic studies revealed that adsorption process followed the pseudo-second-order kinetic model. This implies that chemisorption is the rate-limiting step in the adsorption process.

Although other adsorbents have shown the same or even greater adsorption efficiencies, as Duolite GT-73 [46], rice husk has high availability and low cost. This indicates that the RHc300 material, which requires less energy investment than rice husk ash, could be an excellent alternative for removing $\mathrm{Cd}$ (II) from aqueous media for $\mathrm{pH}$ values ranging from 4 to 6.

\section{Conflicts of Interest}

The authors declare that there are no conflicts of interest regarding the publication of this paper.

\section{Acknowledgments}

The authors acknowledge University of Tolima for the financial support (Project code 860113). The authors also thank Group on Porous Solids and Calorimetry, Department of Chemistry, Faculty of Science, University of the Andes, for experimental support.

\section{References}

[1] J. H. Duffus, “"Heavy metals”-a meaningless term?” Pure and Applied Chemistry, vol. 75, no. 9, article 1357, 2003.

[2] Z. Rengel, Heavy Metals as Essential Nutrients, Springer, Berlin, Heidelberg, Germany, 2004.

[3] U. Forstner and G. T. W. Wittmann, Metal Pollution in the Aquactic Environment, Springer, 2nd edition, 1979.

[4] O. Barbier, G. Jacquillet, M. Tauc, M. Cougnon, and P. Poujeol, "Effect of heavy metals on, and handling by, the kidney," Nephron - Physiology, vol. 99, no. 4, pp. 105-110, 2005.

[5] G. Kazantzis, "Cadmium, osteoporosis and calcium metabolism," BioMetals, vol. 17, no. 5, pp. 493-498, 2004.

[6] J. Y. Barbee Jr. and T. S. Prince, "Acute respiratory distress syndrome in a welder exposed to metal fumes," Southern Medical Journal, vol. 92, no. 5, pp. 510-512, 1999.

[7] J. Godt, F. Scheidig, C. Grosse-Siestrup et al., "The toxicity of cadmium and resulting hazards for human health," Journal of Occupational Medicine and Toxicology, vol. 1, article 22, 2006.

[8] A. Bożęcka, M. Orlof-Naturalna, and S. Sanak-Rydlewska, "Removal of lead, cadmium and copper ions from aqueous solutions by using ion exchange resin C 160," Gospodarka Surowcami Mineralnymi, vol. 32, no. 4, pp. 129-140, 2016.

[9] S. He, B. Ruan, Y. Zheng, X. Zhou, and X. Xu, "Immobilization of chlorine dioxide modified cells for uranium absorption," Journal of Environmental Radioactivity, vol. 137, pp. 46-51, 2014.

[10] W.-Q. Zhuang, J. P. Fitts, C. M. Ajo-Franklin, S. Maes, L. Alvarez-Cohen, and T. Hennebel, "Recovery of critical metals using biometallurgy," Current Opinion in Biotechnology, vol. 33, pp. 327-335, 2015.

[11] H. Wang and Z. J. Ren, "Bioelectrochemical metal recovery from wastewater: A review," Water Research, vol. 66, pp. 219232, 2014.

[12] V. K. Gupta and I. Ali, "Utilisation of bagasse fly ash (a sugar industry waste) for the removal of copper and zinc from wastewater," Separation and Purification Technology, vol. 18, no. 2, pp. 131-140, 2000.

[13] S. Basha, Z. V. P. Murthy, and B. Jha, "Sorption of Hg(II) onto carica papaya: experimental studies and design of batch sorber," Chemical Engineering Journal, vol. 147, no. 2-3, pp. 226-234, 2009.

[14] A. Saeed, M. Iqbal, and W. H. Höll, "Kinetics, equilibrium and mechanism of $\mathrm{Cd} 2+$ removal from aqueous solution by mungbean husk," Journal of Hazardous Materials, vol. 168, no. 2-3, pp. 1467-1475, 2009.

[15] J. Anwar, U. Shafique, Waheed-uz-Zaman, M. Salman, A. Dar, and $\mathrm{S}$. Anwar, "Removal of $\mathrm{Pb}(\mathrm{II})$ and $\mathrm{Cd}(\mathrm{II})$ from water by adsorption on peels of banana," Bioresource Technology, vol. 101, no. 6, pp. 1752-1755, 2010.

[16] N. Azouaou, Z. Sadaoui, A. Djaafri, and H. Mokaddem, "Adsorption of cadmium from aqueous solution onto untreated coffee grounds: equilibrium, kinetics and thermodynamics," Journal of Hazardous Materials, vol. 184, no. 1-3, pp. 126-134, 2010.

[17] V. Lugo-Lugo, C. Barrera-Díaz, F. Ureña-Núñez, B. Bilyeu, and I. Linares-Hernández, "Biosorption of $\mathrm{Cr}$ (III) and $\mathrm{Fe}(\mathrm{III})$ in single and binary systems onto pretreated orange peel," Journal of Environmental Management, vol. 112, pp. 120-127, 2012.

[18] C. R. T. Tarley and M. A. Z. Arruda, "Biosorption of heavy metals using rice milling by-products. Characterisation and application for removal of metals from aqueous effluents," Chemosphere, vol. 54, no. 7, pp. 987-995, 2004

[19] X. Liu, X. Chen, L. Yang, H. Chen, Y. Tian, and Z. Wang, "A review on recent advances in the comprehensive application of rice husk ash," Research on Chemical Intermediates, vol. 42, no. 2, pp. 893-913, 2016.

[20] Renu, M. Agarwal, and K. Singh, "Heavy metal removal from wastewater using various adsorbents: a review," Journal of Water Reuse and Desalination, 2016, article jwrd2016104.

[21] U. Kumar and M. Bandyopadhyay, "Sorption of cadmium from aqueous solution using pretreated rice husk," Bioresource Technology, vol. 97, no. 1, pp. 104-109, 2006.

[22] A. Chakraverty, P. Mishra, and H. D. Banerjee, "Investigation of combustion of raw and acid-leached rice husk for production of pure amorphous white silica," Journal of Materials Science, vol. 23, no. 1, pp. 21-24, 1988.

[23] S. Chandrasekhar, K. G. Satyanarayana, P. N. Pramada, P. Raghavan, and T. N. Gupta, "Review processing, properties and applications of reactive silica from rice husk-an overview," Journal of Materials Science, vol. 38, no. 15, pp. 3159-3168, 2003.

[24] B. S. Ndazi, S. Karlsson, J. V. Tesha, and C. W. Nyahumwa, "Chemical and physical modifications of rice husks for use as composite panels," Composites Part A: Applied Science and Manufacturing, vol. 38, no. 3, pp. 925-935, 2007.

[25] B. S. Ndazi, C. Nyahumwa, and J. Tesha, "Chemical and thermal stability of rice husks against alkali treatment," BioResources, vol. 3, no. 4, pp. 1267-1277, 2008.

[26] P. T. Williams and N. Nugranad, "Comparison of products from the pyrolysis and catalytic pyrolysis of rice husks," Energy, vol. 25 , no. 6, pp. 493-513, 2000. 
[27] D. Sud, G. Mahajan, and M. P. Kaur, "Agricultural waste material as potential adsorbent for sequestering heavy metal ions from aqueous solutions-a review," Bioresource Technology, vol. 99, no. 14, pp. 6017-6027, 2008.

[28] N. Soltani, A. Bahrami, M. I. Pech-Canul, and L. A. González, "Review on the physicochemical treatments of rice husk for production of advanced materials," Chemical Engineering Journal, vol. 264, pp. 899-935, 2015.

[29] H. Yang, R. Yan, H. Chen, D. H. Lee, and C. Zheng, "Characteristics of hemicellulose, cellulose and lignin pyrolysis," Fuel, vol. 86, no. 12-13, pp. 1781-1788, 2007.

[30] T. N. Ang, G. C. Ngoh, and A. S. M. Chua, "Comparative study of various pretreatment reagents on rice husk and structural changes assessment of the optimized pretreated rice husk," Bioresource Technology, vol. 135, pp. 116-119, 2013.

[31] V. P. Della, I. Kühn, and D. Hotza, "Rice husk ash as an alternate source for active silica production," Materials Letters, vol. 57, no. 4, pp. 818-821, 2002.

[32] R.-S. Bie, X.-F. Song, Q.-Q. Liu, X.-Y. Ji, and P. Chen, "Studies on effects of burning conditions and rice husk ash (RHA) blending amount on the mechanical behavior of cement," Cement and Concrete Composites, vol. 55, pp. 162-168, 2015.

[33] S. Chakraborty, S. Chowdhury, and P. Das Saha, "Adsorption of Crystal Violet from aqueous solution onto $\mathrm{NaOH}$-modified rice husk," Carbohydrate Polymers, vol. 86, no. 4, pp. 1533-1541, 2011.

[34] M. Rozainee, S. P. Ngo, A. A. Salema, and K. G. Tan, "Fluidized bed combustion of rice husk to produce amorphous siliceous ash," Energy for Sustainable Development, vol. 12, no. 1, pp. 3342, 2008.

[35] M. Akhtar, S. Iqbal, A. Kausar, M. I. Bhanger, and M. A. Shaheen, "An economically viable method for the removal of selected divalent metal ions from aqueous solutions using activated rice husk," Colloids and Surfaces B: Biointerfaces, vol. 75, no. 1, pp. 149-155, 2010.

[36] X. Luo, Z. Deng, X. Lin, and C. Zhang, "Fixed-bed column study for $\mathrm{Cu} 2+$ removal from solution using expanding rice husk," Journal of Hazardous Materials, vol. 187, no. 1-3, pp. 182-189, 2011.

[37] T.-H. Liou and S.-J. Wu, "Characteristics of microporous/ mesoporous carbons prepared from rice husk under base- and acid-treated conditions," Journal of Hazardous Materials, vol. 171, no. 1-3, pp. 693-703, 2009.

[38] A. Erto, L. Giraldo, A. Lancia, and J. C. Moreno-Piraján, "A comparison between a low-cost sorbent and an activated carbon for the adsorption of heavy metals from water," Water, Air, and Soil Pollution, vol. 224, no. 4, article no. 1531, pp. 1-10, 2013.

[39] N. A. Medellin-Castillo, R. Leyva-Ramos, R. Ocampo-Perez et al., "Adsorption of fluoride from water solution on bone char," Industrial and Engineering Chemistry Research, vol. 46, no. 26, pp. 9205-9212, 2007.

[40] T. H. Baig, A. E. Garcia, K. J. Tiemann, and J. L. GardeaTorresdey, "Adsorption of heavy metal ions by the biomass of Solanum elaeagnifolium (Silverleaf night-shade)," in Proceedings of the Hazardous Waste Research, pp. 131-142, 1999.

[41] K. K. Krishnani, X. Meng, C. Christodoulatos, and V. M. Boddu, "Biosorption mechanism of nine different heavy metals onto biomatrix from rice husk," Journal of Hazardous Materials, vol. 153, no. 3, pp. 1222-1234, 2008.

[42] V. C. Srivastava, I. D. Mall, and I. M. Mishra, "Characterization of mesoporous rice husk ash (RHA) and adsorption kinetics of metal ions from aqueous solution onto RHA," Journal of Hazardous Materials, vol. 134, no. 1-3, pp. 257-267, 2006.
[43] V. C. Srivastava, I. D. Mall, and I. M. Mishra, "Adsorption thermodynamics and isosteric heat of adsorption of toxic metal ions onto bagasse fly ash (BFA) and rice husk ash (RHA)," Chemical Engineering Journal, vol. 132, no. 1-3, pp. 267-278, 2007.

[44] Y. S. Ho, "Review of second-order models for adsorption systems," Journal of Hazardous Materials, vol. 136, no. 3, pp. 681689, 2006.

[45] P. S. Kumar, K. Ramakrishnan, S. D. Kirupha, and S. Sivanesan, "Thermodynamic and kinetic studies of cadmium adsorption from aqueous solution onto rice husk," Brazilian Journal of Chemical Engineering, vol. 27, no. 2, pp. 347-355, 2010.

[46] T. Vaughan, C. W. Seo, and W. E. Marshall, "Removal of selected metal ions from aqueous solution using modified corncobs," Bioresource Technology, vol. 78, no. 2, pp. 133-139, 2001. 

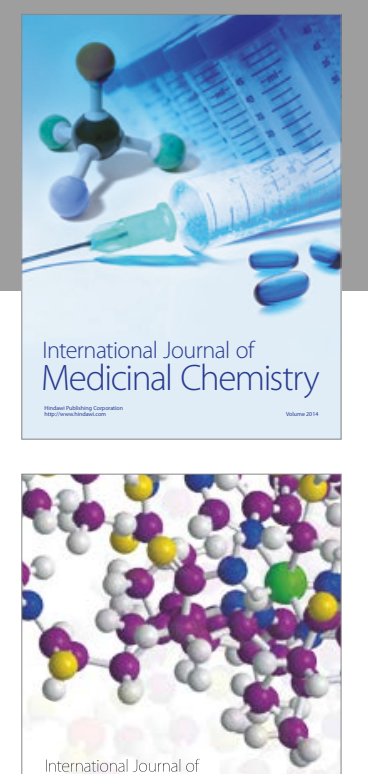

Carbohydrate Chemistry

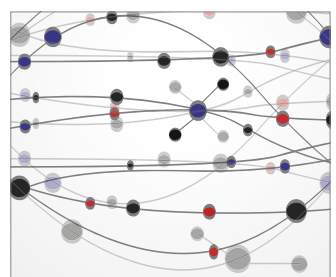

The Scientific World Journal
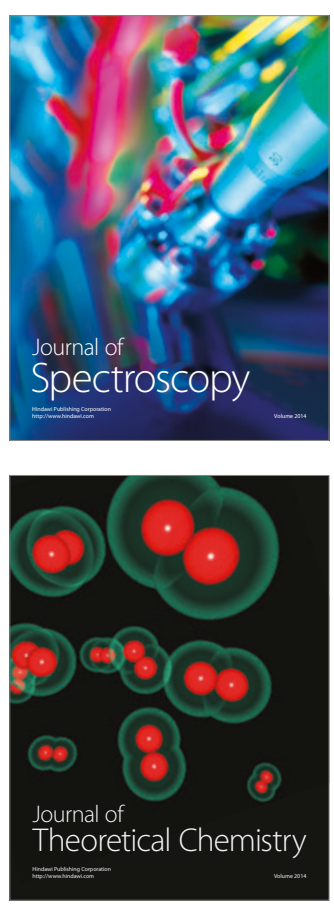
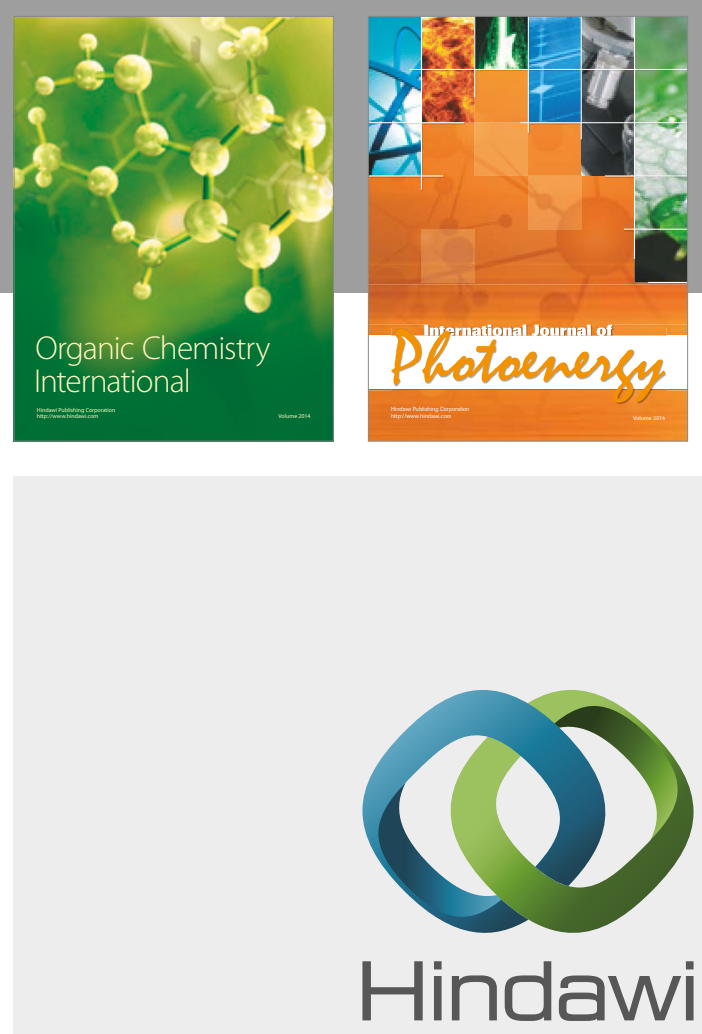

Submit your manuscripts at

https://www.hindawi.com

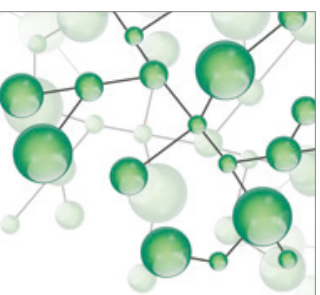

International Journal of

Inorganic Chemistry

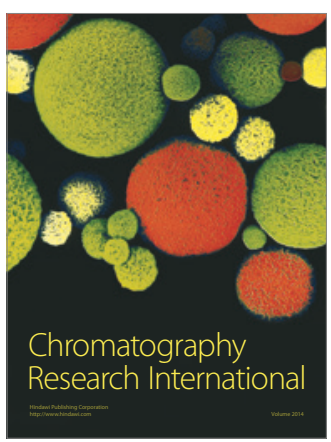

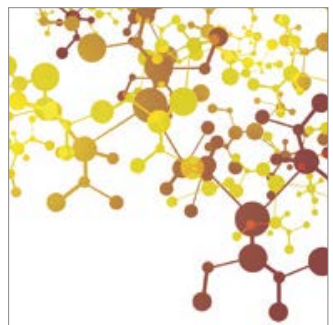

Applied Chemistry
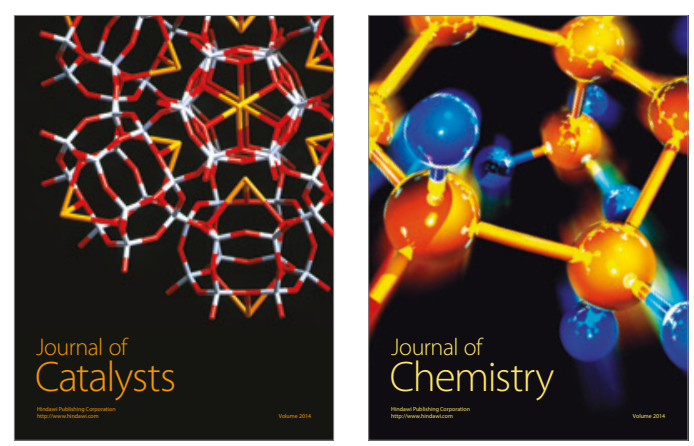
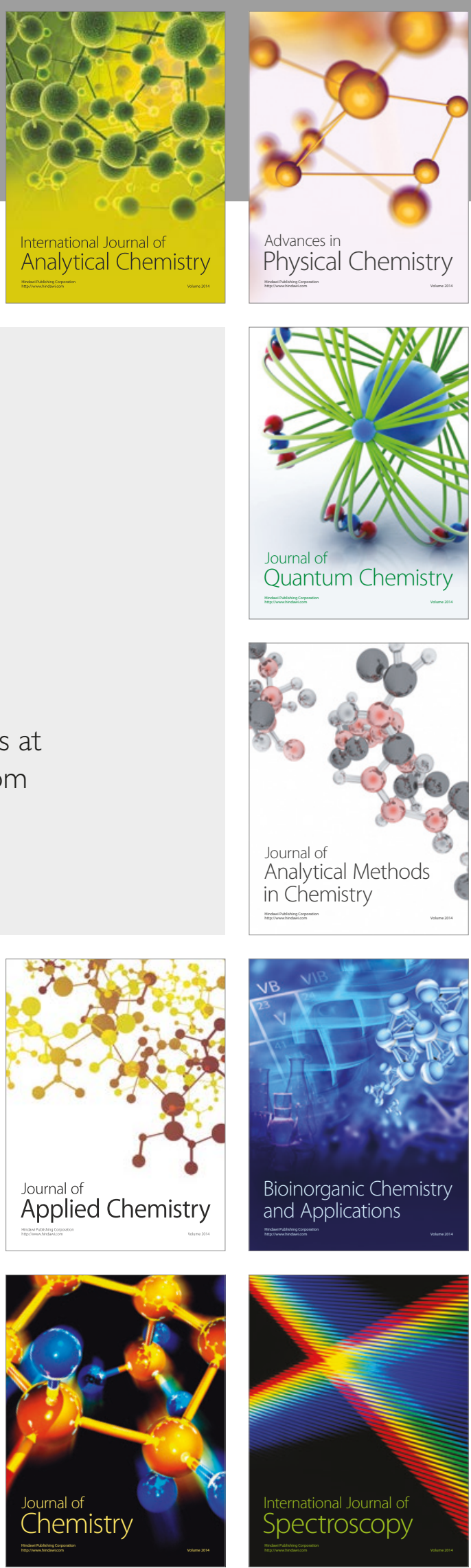